\title{
Brazil's recognition of Palestinian State in 2010
}

Rasem S. M. Bisharat

\begin{abstract}
This paper examines the Brazilian recognition of the Palestinian state, as one of the initiatives of the Lula government. It deals with the question of a Palestinian state within a clear border (1967 borders) and East Jerusalem within these borders. It concludes with recommendations for the Brazilian left and the Palestinian community in order not to undermine the status of the Palestinian cause in the Brazilian political arena.
\end{abstract}

KEYWORDS: Brazil. State of Palestine. Peace process. Israeli occupation. Middle East.

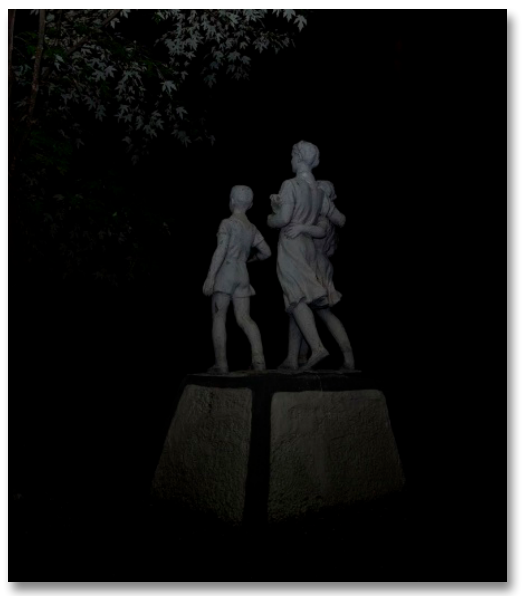

\section{RASEM S. M. Bisharat}

Palestinian, Doctor of Philosophy by Jamia Millia Islamia in New Delhi and Coordinator of International Relations of the Universidade de Políticos do Movimento Popular UNIPOP- Brasilia. E-mail: rasembisharat@gmail.com.
RESUMO: Este artigo examina o reconhecimento brasileiro do estado palestino, como uma das iniciativas do governo Lula. O artigo aborda a questão de um estado palestino dentro de uma fronteira clara (fronteiras de 1967) e com Jerusalém Oriental dentro dessas fronteiras. E conclui com recomendações para a esquerda brasileira e a comunidade palestina para não prejudicar o status da causa palestina na arena política brasileira.

PALAVRAS-CHAVE: Brasil. Estado da Palestina. Processo de paz. Ocupação israelense. Oriente Médio.

RECEBIDO EM: 03/12/2017

APROVADO EM: $31 / 12 / 2017$ 


\section{INTRODUCTION}

The Middle East in general and the Arab region are important strategic area for global powers since the ancient times. Its importance relates to its geographical location, which links the various continents and controls important straits such as the Suez Canal and Bab el Mandeb. In addition, the availability of natural resources in the region has increased its importance. This has attracted the attention of super powers.

The third millennium witnessed a prominence of unique Brazilian identity in the international regime, coincided with the rise of Workers' Party (known in Portuguese as Partido dos Trabalhadores - PT) to power under the leadership of President Luiz Inacio Lula da Silva, because of its size as a continental state like the United States of America - (USA), Russia, China, and India. It is the fifth biggest country in the world according to its population and size, a little less than half of the continent's size. The number of its population is estimated 200 million people; half of them are work force. Brazil is the largest economy in South America and the second largest in Americas. It is also the sixth largest economy in the world.

The Brazilian foreign policy makers consider the Arab region as one of great interest since the last two decades; Brazil opened its foreign policy to the Arab World during the tenure of President Lula. The opening of foreign policy took different forms such as economic relations connected with political interest at high levels; which was expressed in the Summit of South American - Arab Countries(ASPA). The political relations were boosted under the leadership of Brazil. Brazil took up a campaign on behalf of Latin American countries to recognize the State of Palestine based on 1967 borders with East Jerusalem as its capital.

Brazilian interest in the Palestinian cause was surprising, even among Brazilians themselves, wondering why Brazil's foreign policy was interested in a cause outside Brazil's orbit. One of the reasons for that interest came because of the existence of a large Arab community as well as an important Jewish community. Brazil is a home of an Arab community estimated at about ten million and a Jewish community estimated at about 120 thousands. 
This paper argues that the Brazilian position on the issue of recognition of the Palestinian state comes within two fundamental issues related to the Brazilian foreign policy. First, the recognition came as a complement to the second chapter of partition resolution 181, which adopted by the United Nations General Assembly (UNGA), in November 1947, which proposed the division ofhistorical Palestine into two states: Jewish and Arab. The new Brazilian recognition came as an unprecedented initiative for Brazil when it stressed the borders of the Palestinian state (the 1967 borders), including East Jerusalem. It also represented a correction of the historical injustice against Palestine, in which Brazilian foreign policy took part when it voted in favor of Partition Resolution 181-2 on 29 November 1947 by the UNGA. The session was presided over by the former Foreign Minister of Brazil, Oswaldo Aranhia.

The other issue is that the Brazilian recognition was the main factor which urged the Palestinian leadership's orientation to the UNGA to seek membership for the state of Palestine. The Palestinian leadership was aware that Brazilian recognition would not stand at the doors of Itamaraty (Brazilian Foreign Ministry). It would have a significant impact on South America and the rest of the Latin American countries. The Palestinians believe that the Brazilian recognition would guarantee two-thirds of the votes of the UNGA to ensure the Palestine's membership.

The paper also presents several recommendations came in light of the change of the political system in Brazil. Those changes were summarized by the exclusion of the legitimate president and the establishment of a right-wing government who stands against the policies of the previous government. The current government policy may affect the status of the Palestinian cause in the Brazilian political agenda, that status which established by the previous government led by Lula and Rousseff. Therefore, the Brazilian left-wing and the Arab communities, especially the Palestinian, have to work on building a new plan and policy to deal with the new changes, so as not to prejudice the status of the Palestinian cause in the Brazilian foreign policy and maintain the gains accomplished by the PT's government in favor of the Palestinian cause. 
The second presidential term of President Lula (early 2007 end of 2010) witnessed an active and effective Brazilian foreign policy towards the peace process and the Palestinian cause. This was represented by suggestions about several political initiatives to contribute to solve the Palestinian cause with a fair and permanent solution which leads to the establishment of an independent, democratic and economically viable state living in peace and security alongside the State of Israel.

\section{THE PALESTINIAN EYES ON LATIN AMERICA}

Two main factors have helped to direct the attention of the Palestinian leadership to Latin America in general and to Brazil in particular in searching for other allies and embarrass the US administration that manages the Middle East file. These factors were represented by the rise of the Left in Latin America in many countries of the continent, including Brazil, accompanied by a general trend in the continent to oppose the American policies and adopt an independent policies. In addition to the revitalization and mobilization of Palestinian Diaspora organizations in the continent after the start of the second intifada in 2000, which opened the way for the Palestinian diplomacy to enter the Latin American continent and pursue an efficient and active diplomatic policy.

The rise of the Left in the continent had affected on the Palestinian cause positively. In addition, the year 2007 witnessed the brightest era for the Left in Latin America, which witnessed the arrival of Left-wing parties to power in several countries of the continent, particularly where they are considered important for Brazil, such as Rafael Correa in Ecuador, Daniel Ortega in Nicaragua, Cristina Kirchner in Argentina, who replaced her husband, Nestor Kirchner. In Venezuela, President Hugo Chavez began his third term, as well as other left-wing parties in countries such as Cuba and Bolivia.

The Palestinian cause in the eyes of the Brazilian left-wing forces represents the spearhead in challenging imperialism. They believe that the Palestinian cause is a vivid example of the imperialist aggression against humanity, which put it at the forefront 
of their concerns. In addition to the involvement of Brazilians of Palestinian, Lebanese and Syrian origins in all Brazilian parties, organizations and federations, which contribute more to the remarkable presence of the Palestinian cause in the Brazilian political scene.

According to the activity of the organizations of the Palestinian Diaspora, the Palestinian community in Brazil, which numbers about 60 thousand, most of them are concentrated in the states of Rio Grande do Sul, Goias, Paraná, Pernambuco, Rio de Janeiro, in addition to Brasilia DF. It is active through several organizations and institutions since the end of the sixties of the last century, in the form of cultural centers, federations and associations. A general conference for the community usually holds every few years in which all institutions in Brazil participated, the latest of which was the Ninth Congress which was held on January 26 $6^{\text {th }}, 2007$.

The organizations of the Palestinian community in Brazil have relations and connections with the Palestinian National Authority -(PNA) and the Palestinian leadership from various Palestinian parties in Palestine. The Palestinian leadership interacts with community events in Brazil and in Latin American countries. At the Ninth Conference of the Community, Mrs. Mayada Bamya, the former Palestinian Ambassador to Brazil, represented the President Mahmoud Abbas, and delivered a speech at the Conference on his behalf. The President affirmed the pride of the Palestinian leadership on the efforts and activities of the community in the Brazilian arena, which aimed to provide backup and support to the Palestinian people in their just struggle for freedom and independence (MAZIN, 2007).

It was rare for any visit of an official Palestinian to Brazil not to meet the Palestinian community and provide a detailed explanation of the latest developments and updates on the Palestinian situation, and the situation in the Middle East in general. The Palestinian President was interested in communicating with the Palestinian community. In his visit to Brazil in 2009 for instance, he met with the Palestinian community in the state of Rio Grande do Sul on November $21^{\text {st }}, 2009$ (MRE, 2009b). 
Palestinian Diaspora organizations in the continent including Brazil have been active in the defense of Palestinian rights, and have contributed with political parties, trade unions and social groups to rally a support for the Palestinian cause during the past years. In Brazil, its activity was strong, clear and influential. It contributed in many significant achievements in terms of support for the Palestinian cause, and was active in the committees of solidarity with the Palestinian people in Brazil, such as the campaign of "Estado da Palestina Ja", the protests against Israeli attacks on Gaza, and contributed with Brazilian organizations in the refusal of the Brazilian government to accept the nomination of Israeli Ambassador, Danny Dayan, to Brazil. According to Movimentos... (2012), the most important of these institutions and organizations in Brazil include:

- Federação Árabe Palestina do Brasil(FEPAL);

- União de Entidades Palestinas do Brasil;

- Instituto da Cultura Árabe - (ICARABE);

- Comitê Catarinense de Solidariedade ao Povo Palestino;

- Instituto Jerusalém do Brasil - (IJB).

The Government of President Lula has also contributed in mobilizing the communities to support the Palestinian cause and support the Palestinian people. Brazil has called on Palestinian communities throughout Latin America, especially businessmen of Palestinian origin, to hold an economic conference to support the Palestinian economy in the Palestinian territories. This was to be under the title of Economic Conference of the Palestinian Diaspora "ConferenciaEconomica da Diaspora Palestina" at the end of 2010, which was sponsored by the Brazilian government to encourage investment in the Occupied Palestinian Territories (PAIM, 2014).

The Palestinian President pursued a systematic policy with South American countries in 2009, asking all countries of the continent to recognize the Palestinian state, and support of those countries for the Palestinian demand, which was submitted to the Security Council (SC), demanding the full membership of a Palestinian state. For this purpose, President Mahmoud Abbas 
visited Brazil, Chile, Argentina, Paraguay and Venezuela (BAEZA, 2011).

Palestinian President addressed President Lula and the Brazilian people in Brazil's celebration of the Day of Liberation from slavery, which took place in Brasilia on November $20^{\text {th }}, 2009$, describing the Israeli occupation as a gruesome form of slavery. He called the Brazilian people to defend the right of the Palestinian people to gain their freedom and independence, by saying:

True freedom is to defend the freedom of others as you defend your freedom, and seeks the Palestinian people today with all determination and steadfastness to achieve freedom and free from the handcuffs of the occupation. Keep going friends [...] On this day, Black Awareness Day, in solidarity with all those who are still struggling for their freedom and independence. (MAZIN, 2009)

He talked in his speech about the Israeli practices against the Palestinian people, the suffering of the Palestinians because of the practices of the occupation, Israel's refusal to abide by the resolutions of international legitimacy and UNGA resolutions:

Confiscates land to build settlements, uprooting trees to deprive the farmer of the production of his land, erects a wall of apartheid that prevents the students to reach schools, and closes the city of Jerusalem in front of Palestinian believers; Christians or Muslims. We believed that the Israeli side would respond to international demands and would respect the legitimacy and resolutions of the United Nations, but instead, continues the policy of ethnic cleansing of the Palestinian presence in the city of Jerusalem, practices all forms of oppression, aggression, and commits massacres. (MAZIN, 2009).

It seems that the efforts of President Abbas and his diplomacy, which followed Israel's disavowal of its commitment to the results of the Annapolis Conference and its continuation in settlement policy, has made a significant impact on the Brazilian position regarding the Palestinian state. This position came by Maria Luiza Ribeiro Viotti, Brazil's Ambassador to the SC, on January $7^{\text {th }}$, 
2009, who called for an independent Palestinian state within internationally recognized borders, by stating that a lasting peace in the Middle East would be achieved only through the establishment of an independent Palestinian state, coexisting with Israel, within internationally recognized borders in accordance with SC resolutions (MRE, 2009a).

\section{ISRAELI SETTLEMENT AND NEGOTIATIONS}

The Israeli settlement process in the Occupied Palestinian Territories has not stopped even with the commencement of the Peace Process in 1993, which has led to an increase in the pace of settlement since. The settlement process has led to doubling of the number of settlements and the number of settlers in 2010 were 199 settlements with nearly six hundred thousand. The settlement area doubled from 69 square kilometers, about 1.2 percent of the West Bank, and reached to about 189 square kilometers, equivalent to 3.3 percent of the total area of the West Bank. Throughout that period, European and American mediators have not been able to freeze or halt Israeli settlement activities, making the two-state solution impossible. The pace of settlement activity increased markedly in the period after 2006, despite repeated warnings by the US administration to Israel, demanding it to stop settlement activity in the Palestinian territories, making it an obstacle for the Israeli-Palestinian Peace Process.

At the same time, it is a violation of Israel to its commitments, which haddid at the Annapolis Conference in November 2007. Israeli Prime Minister Ehud Olmert said in his speech that the negotiations between the Israeli and Palestinian sides to resolve the dispute will be based on the agreements signed between the two sides, SC Resolutions 242, 338, the Road Map and the letter of President George W. Bush on April 14th, 2004 , to Israeli Prime Minister Ariel Sharon. Israeli Prime Minister Ehud Olmert pledged to the members of the Israeli cabinet, on November $19^{\text {th }}, 2007$, to freeze settlement activities in West Bank settlements and dismantle settlement outposts, a move which the international community has seen as a goodwill gesture by the Israeli government to push 
forward the Peace Process. Olmert added that the roadmap included a clear commitment by the Israeli government not to build new settlements and new neighborhoods in West Bank, not to confiscate land, therefore, the Israeli government must implement these commitments (ISRAELI PLANS..., 2010).

Palestinian President Mahmoud Abbas summed up the Israeli policies in the Palestinian territories, during his address in the European Parliament in Strasbourg, in February 2009. These policies were the reasons for the suspension of the negotiations. They were the settlements activities and the settlers' terrorism against Palestinian people under protection of the Israeli army, the military attacks against Palestinian civilians by the Israeli army, the violations of the Israeli side on all agreements and understandings on the Peace Process, that are supposed to lead to the establishment of an independent Palestinian state (MAZIN, 2009).

Illegal Israeli settlement activity has caused worries to the international community. In June 2009, the European Union (EU) issued a statement expressing its concern over continued settlement and demolition of homes, including East Jerusalem. The EU called on the Israeli government to end settlement activities including natural growth, and end the activities in East Jerusalem. It also called on Israel to dismantle all settlement outposts established since March 2001, assuring that the settlements were illegal (CEU,2010).

In his speech in Santiago, Chile, on the International day of Solidarity with the Palestinian People, on November $26^{\text {th }}, 2009$, President Abbas said that the results of these policies led to the deadlock in the Peace Process and to the conviction that the Israeli side was not serious about moving ahead with peace (MAZIN, 2009).

During 2010, Israel's policy of confiscation of the lands in the Occupied Palestinian Territories continued under various pretexts and arguments, for building more settlements, and expanding existing settlements by a unilateral move aimed to strengthen its control over the Palestinian territories and imposing a de facto policy. The area of Palestinian land confiscated in the West Bank was 13,334 dunums in 2010 only, most of which was in Ramallah and Hebron. These violations were considered as infraction of 
the Fourth Geneva Convention of 1949, article 147, which states that the destruction and rape of property, in a manner not justified by military necessity, and on a large scale in an illegal and arbitrary manner is a grave violation of the Convention. Article 49 of the Fourth Geneva Convention, which states that the Occupying Power has no right to transfer its citizens to the territories which it has occupied, or to carry out any action leading to any demographic change. These violations also contradict article 17 of the Universal Declaration of Human Rights of 1948, which states that no one shall be arbitrarily deprived of his property (ISRAELI VIOLATIONS..., 2010).

The Palestinian position on returning to the negotiations was conditioned on a halt to settlement activity and Israel's acceptance of a two-state solution. This was rejected by Israel and it continued in its policies aimed to eliminate the option of a two-state solution, for which international resolutions and understandings have been committed (MAZIN, 2009).

Brazil has been followed, with deep concern, the developments in the Middle East, particularly Israel's settlement policy, land confiscation and expansion of settlements based on Palestinian land. Brazil considered these violations as serious obstacles to the two-state solution. In his speech at the International Conference in Support of the Palestinian Economy and the Reconstruction of Gaza, held in Sharm el-Sheikh, on March $2^{\text {nd }}, 2009$, Celso Amorim called on the new Israeli government to abide by the Peace Process and to end the serious obstacles to the two-state solution. In a press release issued on November $19^{\text {th }}, 2009$, the Brazilian government condemned the Israel's decision to build 900 housing units in the Gilo settlement in East Jerusalem. It considered this act as a violation to UNSC resolutions and a violation to the Road Map. It constitutes a severe blow to international efforts to resume the Peace Process in the region, and an obstacle to the establishment of an economically independent and a viable Palestinian state (MRE, 2010).

In a statement issued by President Lula on November $20^{\text {th }}$, 2009, when Palestinian President Mahmoud Abbas visited Brazil, he called for the establishment of a just and lasting peace in the 
region based on the establishment of a prosperous and cohesive Palestinian state. He expressed his rejection to the expansion of Israeli settlements in the West Bank (MRE, 2010).

\section{THE BRAZILIAN RECOGNITION}

One of the options put forward by the Palestinian leadership in the light of the continuation of Israeli policy in the Palestinian territories and its rejection of the settlement freeze, is to resort to the SC to obtain recognition by the international organization of the state of Palestine. If the SC failed to adopt a resolution of recognition because of the expected veto by the USA, the Palestinian leadership would approach the General Assembly.

In that case, two thirds of the votes of the members of the UNGA must be obtained, which means 129 out of the 193-member states. It should be noted that applying for membership in the General Assembly to recognize a Palestinian state is a moral victory. It cannot be translated into reality, even if the Palestinians declare their state as they did on 15 November 1988. However, the resolution may force Israel to engage in serious negotiations between the two states. It could be a legal basis for launching a campaign to expel the occupation from the Occupied Palestinian Territories. It has the right to join all international organizations, namely the Rome Convention, the International Court of Justice and the International Criminal Court. The State of Palestine would become an internationally recognized entity operating under international law to end the occupation by negotiations between two independent and equal states, and to sign a comprehensive peace treaty between two states with the guarantee of the UN. In the case of Israel's intransigence to withdraw from the Palestinian territories, this state can resort to the International Court of Justice and register a formal complaint in the International Criminal Court against Israeli practices on the land of the Palestinian state and against the settlements, as well as the prosecution of Israeli war criminals.

To implement this option, the Palestinian leadership had to mobilize the international position by guaranteeing two thirds of the votes of the UNGA. This prompted the Palestinian President to 
send a letter to the Brazilian President on November 24th 2010 , requesting Brazil's recognition of the Palestinian state mentioning the reasons that prompted the Palestinian leadership to seek recognition and the reasons for approaching Brazil.

The official position of the government of President Lula towards the Palestinian cause was represented by declaring its steadfast position and its vision to resolve the Middle East crisis by supporting all resolutions related to the Palestinian cause, which were issued by UNGA and the SC. In addition, to follow peaceful methods those will lead to the two-state solution with an independent and viable state beside Israel. Brazil strongly supports the establishment of a Palestinian state - independent, democratic, secure, coherent and economically viable state. At the same time, Brazil sees the need to ensure the conditions for the state of Israel to live in peace and security within recognized borders, which is the only viable solution to stability in the region (MRE, 2003).

The Palestinian leadership is aware of the great influence of Brazil on the continent's countries since decades. This has been further boosted after the PT's rise to power, which coincided with the rise of several left-wing parties to power in their own countries. The Palestinian leadership experienced many instances of this influence, especially in 1993 before Lula came to power, when Brazil raised the level of Palestinian representation. In case of President Lula recognizing the Palestinian state, most of the countries in the continent will also do the same. This awareness prompted President Mahmoud Abbas to send a letter asking the Brazilian President to recognize the state of Palestine as an independent state on the borders of the 4th of June 1967.

President Abbas recognized that the Brazilian recognition of the state of Palestine would have an impact and repercussions on the governments of other countries of the continent, which has already happened. The influence of the pro-Palestinian position of President Lula has had positive repercussions on the positions of the countries of the continent in the way of full recognition of a Palestinian state. This was reflected in almost unanimous votes of the countries of the continent with resolution 19/67 of the UN 
General Assembly adopted on November19 ${ }^{\text {th }}, 2012$, recognizing the state of Palestine as a non-member state of the UNGA.

The question of raising the level of the Brazilian recognition of Palestine can be a good example of how Brazil influences the countries of the continent. The representative of the Palestine Liberation Organization (PLO) the former Palestinian Ambassador to Brazil, Dr. Ahmed Soboh (1989-1995), said that specifically after the signing of the Declaration of Principles (Oslo) in September 1993, the Brazilian government negotiated with him about increasing the Brazilian recognition of Palestine. In those negotiations, it was agreed on the status of an advanced diplomat for the mission of Palestine in the Brazilian capital, with privileges, immunities and detailed diplomatic facilities. After a formal exchange of letters between the two sides, a delegation of a Brazilian diplomat handed over the documents to President Yasser Arafat in Tunis in November 1993. What is important in this respect is that other Latin American countries have taken the same Brazilian position. Some of them have adopted the same texts and title for Palestinian mission, such as Argentina, Colombia, Peru and Mexico. ${ }^{1}$

Brazil's recognition of a Palestinian state came through a letter sent by Brazilian President Lula to Palestinian President Mahmoud Abbas on the 1st of December 2010. It came in response to the Palestinian efforts and the letter sent by Palestinian President Mahmoud Abbas to the Brazilian President, on November $24^{\text {th }}$, 2010. Abbas hoped that Brazil will recognize before President Lula's term ended in late 2010.

President Abbas explained in this letter that the Israeli policy in the Palestinian territories led to halt the negotiations and prevented the launching of direct negotiations, and seeks to create a new reality on the ground contradicting the two-state solution. Abbas said that the current situation in the Palestinian territories is witnessing a major escalation in Israeli actions. The Israeli government had refused to stop its settlement activities, which has paralyzed the launching of direct negotiations despite of the international demands of Israel to end the settlements. Israel continues

1 Ahmed Soboh, at e-mail message to author, July 18, 2017. 
to challenge the world and insists on its colonial activities, which hinders any possibility of reaching an agreement through negotiations and creates a new reality that prevents the two-state solution (MRE, 2009b).

In his letter, the Palestinian President explained the reasons that prompted him to ask Brazil to recognize the Palestinian state. Those reasons represented by the valuable and historical Brazilian - Palestinian relations reflected the positions of the Brazilian President regarding the Palestinian people during the past years. The other reason pushing forward he Peace Process is seeking international recognition of the Palestinian state. The Palestinian President believed that Brazil's recognition would encourage other countries in the continent and other parts of the world to recognize the Palestinian state(MRE, 2009b).

The Brazilian recognition came through a letter from the Brazilian President Lula to President Mahmoud Abbas, on December 1st, 2010. President Lula, in the letter, stressed that Brazil historically, and especially during his government (20032010), supported the realization of the legitimate aspirations of the Palestinian people for a cohesive, secure, democratic, and economically viable state, coexisting in peace with Israel. He considered Abbas' request to be just and in accordance with the principles that Brazil has defended on the Palestine cause, and on this basis Brazil recognized a Palestinian state on the 1967 borders.

The Brazilian government defended its position, on recognizing the Palestinian state, by saying that the Brazilian initiative is in line with Brazil's historic position in contributing to the Peace Process between Israel and Palestine, at a time where the process of direct negotiations is in a standstill. This initiative comes in line with international resolutions calling for an end to the Israeli occupation of the Palestinian territories and demands for the establishment of an independent Palestinian state on the borders of June $4^{\text {th }}, 1967$. The Brazilian government stresses that the recognition did not mean abandoning Brazil's conviction that negotiations between Israel and Palestine should be held to achieve mutual concessions on the core issues of the conflict. At the same time, Brazil reaffirmed its historic position in favor of a democratic, geographically 
coherent and economically viable Palestinian state living alongside the state of Israel, which brings security and stability to the region, and meets Israel's legitimate aspirations for security on its borders and peace with its neighbors (MRE, 2009b).

The Brazilian government believed that the initiative was in line with international will, as more than one hundred countries recognize the Palestinian state, including all Arab and Islamic countries, most of African, Asian and Eastern European countries, including countries maintaining relations with Israel, such as Russia, China, India and South Africa; partners of Brazil in the IBSA Forum and BRICS. It noted that the bulk of those recognitions came after the Declaration of Independence adopted by the Palestinian National Council in November 1988 in Algeria (MRE, 2009b).

The PT expressed its absolute support for the decision taken by President Lula, through the President of the party, Rui Falcao, who commented that the PT, throughout its history, has expressed support for a negotiated solution to the conflict, reflecting the coexistence of two states based on the 1967 borders. The party's desire in negotiating between the Palestinian and Israeli sides came to gain an independent, sovereign, democratic and viable State with just and lasting peace in the region for the Palestinians (DATZ; PETERS, 2013).

\section{BRAZILIAN RECOGNITION RESULTS}

The significance of the Brazilian recognition was that it came because of Palestinian diplomatic efforts achieving international victory against Israel. At the same time, it underscored the importance of the political and diplomatic struggle as a method and field of the Palestinian struggle to achieve the Palestinian rights, represented by Israel's withdrawal from the Palestinian territories and the establishment of an independent Palestinian state. Its importance increased as this occurs in the geopolitical sphere of Latin America, and from a country that is respected and considered a leader in the region. This means that the Brazilian initiative will not be restricted to the borders of Brazil, but will extend to other countries in the continent. 
The importance of Brazil and its impact on the continent of South America was clear and immediate. Within three months of Brazil's recognition of the Palestinian state, all the countries of the continent had recognized it, except Colombia. The recognitions extended to the rest of Latin America, where all Latin American countries recognized the Palestinian state except Colombia, Panama and Mexico. This recognition demonstrated the regional leadership of Brazil and its impact on the region, while at the same time angered Israel and the USA.

It is noteworthy that Palestine as a state has been recognized by approximately 100 countries since 1988, when the Palestinian National Council announced on November $15^{\text {th }}, 1988$, in Algiers the establishment of the State of Palestine, the so-called Independence Document. But what is new in the recognition done by Brazil and most Latin American countries is that it guarantees a border to the state, which is the June $4^{\text {th }}, 1967^{\prime}$ 's border. This means that these countries affirm that East Jerusalem lies within the borders of the Palestinian state. It also means the rejection of unilateral measures taken by Israel which seeks to unify Jerusalem and proclaim it as the eternal capital of the state of Israel.

In case of the recognition of Palestine as a full member of the UN, it means that any negotiations between the Palestinian and Israeli sides will move from negotiations between a state and a representative of a people to negotiations between two states - the occupier and the occupied. This requires the intervention of the SC to end the occupation.

One of the important results of this recognition is encouraging the Palestinian leadership to continue the diplomatic struggle to reach a two-state solution. With increased numbers of Latin American countries that had recognized the Palestinian state, the Palestinian leadershiphad pushed forward the slogan "2011 is the year of the Palestinian state". A plan of action had been drawn up for the SC and preparations to go to the UNGA in case the SC failed to pass the decision of Palestine being a member in the UN. Saeb Erekat, head of the Negotiations Affairs Department, called on the USA to support and declare its recognition of the Palestinian state within the 1967 borders, which is the confirmation of the two-state solution called 
for by the Quartet, the Road Map and the Annapolis Conference. If any party is keen on a two-state solution, they must recognize Palestinian state on the 1967 borders (SALEH; SAAD, 2015).

Palestinian Foreign Minister Riyad Al-Malki stressed that recognition by Brazil and South American countries had helped the PNA to gain recognition of the Palestinian state as an independent state in September. He assured that the Palestinian leadership will seek recognition from other countries and this will help to get recognition of Palestine by the UN. Al-Maliki told the BBC: "If Palestine has diplomatic relations and most of the world recognizes the state of Palestine, it would be easy if Palestine had to go to the UNGA to ensure that these countries vote for the Palestinian state." Al-Malki viewed this effort as an important one which helps in preparing the atmosphere, when the time comes, to adopt Palestine as a permanent member of the UN (BUDEIRI, 2010).

Brazil's recognition and subsequent South American recognitions reinforced the choices of the Palestinian leadership to go to the SC and the UNGA, which later succeeded in gaining recognition by the General Assembly of the Palestinian state as a non member state. The Palestinian leadership is currently working on a new approach to the UNGA to request full membership of the state of Palestine.

Several Palestinian political scholars, such as Jamal Zahalka, Asaad Abu Shrakh and Hani al-Masri, believe that the step of the international recognition of the Palestinian state will not change much if it remains a single step and has not been accompanied by serious steps on the ground, such as reconciliation with Hamas, stopping the security coordination and carrying on the struggle against the occupation. Zahalka believes that the Palestine cause cannot be turned into a diplomatic issue of recognition, embassies and decisions. A Palestinian state has been declared in the past and has been recognized by more than 100 countries, and there has been little change. This step must be treated as a step, in support of the Palestinian struggle and not a substitute for it. Hani al-Masri said the negotiations, which took place over 20 years, were illusions without achieving any results and that in case the Palestinian leadership decides to return to bilateral negotiations, Israel must 
declare its readiness to implement international resolutions and engage in negotiations to discuss the mechanism of implementation. At the same time, Palestinians must demand international guarantees and Arab presence (HALIM, 2010).

\section{CONCLUSIONS AND RECOMMENDATIONS}

These days mark the seventh anniversary of Brazil's recognition of the Palestinian state. What has been achieved by this recognition and what the Palestinian cause has gained? What are the achievements on the ground that was in favor of the Palestinian state?

First, the territory of the Palestinian state which included in the Brazilian recognition is still under Israeli occupation. Israel, along with the USA, rejected the Latin American recognitions and attacked the policies of those countries. On the other hand, Israel increased the pace of settlement activity, the confiscation of Palestinian land and the demolition of houses, especially in East Jerusalem, without any deterrent of international legitimacy against Israel, except of SC Resolution No. 2334 in September $23^{\text {rd }}, 2016$, where the administration of President Barack Obama abstained, but like other resolutions, it remained a dead letter, in a clear Israeli message to the international community that carries a practical response in a clear challenge to the resolutions of international legitimacy.

Second, at the Palestinian level, the UNGA recognizes the State of Palestine as an observer. The accession of Palestine to most international organizations, including the International Justice Organization, the International Criminal Court - (ICC), the Rome Statute, The United Nations Educational, Scientific and Cultural Organization - (UNESCO) and the latest the Interpol did not stop the Israeli settlement practices and continues its occupation of the Palestinian territories. It is a State outside international law for its non-compliance with international resolutions, encouraged by the political, military and economic support and protection of the USA.

Third, the world is witnessing several regional and global changes that will have repercussions on the Palestinian cause. The left 
has declined in a number of Latin American countries, western military interventions in the Middle East under the name of fighting the Islamic state (ISIS) and combating terrorism. In addition to a new US administration which is not shy to express its support for Israeli policies and threaten who stand against those policies, including the international organizations.

We believe that the diplomatic battle with Israel will continue and will have positive results on the Palestinian position, but it will not change anything on the ground. Therefore, the Palestinian leadership is required to take realistic measures, internal and external, to face the continuation of the Israeli occupation and stand in front of the expected US pressure, especially in light of the failure of the Arab position, which is witnessing rapprochement with Israel and full compliance with the US position.

Internally, the Palestinian leadership must end the reconciliation file between Fatah and Hamas quickly, which is supervised by Egypt, in order to unify the Palestinian internal front in the face of external challenges, especially in dealing with what the US administration will propose to solve the Middle East problem. The proposal would undoubtedly be in favor of Israel and at the expense of the legitimate rights of the Palestinian people.

Externally, to build an international front against the continued Israeli occupation of the Palestinian and Arab territories in alliance with the forces of the left and pro-justice and peace forces in the world, Palestinian communities abroad are within the leadership of that front. The objectives of the front are expected to achieve two goals:

First: the promotion and expansion of the international campaign for boycott, Divestment and Sanctions (BDS) in order to enforce Israel to respond to the international legitimacy.

Second: To go to all the international organizations to work on the trial of Israel for its crimes, those crimes which amounting to war crimes, especially to the ICC.

The Palestinian communities in Latin America in general and Brazil in particular have to do more than what they had done during the era of the PT government in Brazil. The decline of the left forces in the continent and the Israeli attempts to conquer the 
region again are the main reasons for the need to activate and increase its efforts against those changes in order to maintain the forefront of the Palestinian cause in the agendas of the governments on the continent, regardless of its tendencies and directions such as the interim government formed by Michel Temer.

When Jose Serra was appointed as Minister of Foreign Affairs in the interim government of Temer, in the wake of the removal of President Dilma Rousseff from the presidency of Brazil, he said on May $18^{\text {th }}, 2016$, that the new government will care about the interests of Brazil's economy rather than goals left-wing ideology. Brazil will not be anymore part of the broad left-wing alliance found in many Latin American countries. Brazil will return to reflect firmly and transparently legitimate values of the Brazilian society and economic interests, serve all Brazilians, and will not return to the preferences of the ideology of a political party or foreign allies. The last statement after less than a month on his appointment, Serra announced that the country will reconsider the vote made recently in favor of UNESCO's decision on Jerusalem, which urges Israel to stop the attacks and illegal measures against freedom of worship and the arrival of Muslims to their holy places (BAEZA, 2017).However; Brazil has not changed its position, the Government of Temer has voted in favor of several resolutions in UNESCO related to Palestinian rights in Jerusalem and Al-Aqsa Mosque.

Finally, Cecilia Baeza, a member of the Palestinian Policy Network and a lecturer at the Giulio Vargas Foundation in Sao Paulo, believes that the Palestinian communities and popular campaigns have greater responsibilities than previously to lead the popular movements to remind the governments of the continent of their human rights responsibilities, continue the supporting of the Palestinian cause and play a role in boycotting Israel. Therefore, the leftist and progressive forces, as well as the Palestinian community in Brazil, must recall the memories of the 1980s and 1990s to build on these experiences. They should raise the degree of joint coordination in activities and electoral battles, building new mechanisms to deal with the new reality and activating the São Paulo Forum by new means and strategies. 
The launch of the Brazil Palestine institute (IBRASPAL) in Sao Paulo, on October $20^{\text {th }}, 2017$, and held the Fourth Congress of the Confederation of Palestinian Communities in Latin America and the Caribbean, Congresso da Confederação da Palestinana América Latina e no Caribe-(COPLAC)in Managua, on October $19^{\text {th }}-22^{\text {nd }}$, 2017, should be the beginning of re-unite all the support forces of Palestine cause in Latin America and particularly in Brazil in order to face any changes in the foreign policy of Brazilian government towards Palestine and its cause.

\section{REFERENCES}

HALIM, H. A. Recognition of the Palestinian state. Arab 48, [online], Jan. 14, 2010. Available at:<http://www.arab48.com/>. Accessedon: May 20, 2018.

BAEZA, C. O reconhecimento do Estado palestino: origens e perspectivas. Meridiano 47, Brasília, v. 12, n. 126, p. 34-42, 2011.

Latin America's Turn to the Right: Implications for Palestine. Alshabaka: the Palestinian policy network, [online], Jan. 10, 2017. Available at: $<$ http://www.al-akhbar.com/node/275013>. Accessed on: May 20, 2018.

BUDEIRI, A. Israel is losing South America and the Palestinians are seeking for European recognition of their independence.BBC Jerusalem, [online], Jan. 10, 2010. Available at: <http://www.bbc.com/arabic/ middleeast/2011/01/110105_israel_diplomacy.shtml>. Accessed on: May 20, 2018.

CEU - Council of the European Union. Declaration by the Presidency on behalf of the EU on Israeli settlements, 13044/1/09 (Press 262), Brussels, 9/9/2009. In: SALEH, M. (ed.). The Palestinian Strategic Report 2009. Beirut: Al-Zaytouna Centre for Studies \& Consultations, 2010. p. 119.

DATZ, G.; PETERS, J. Brazil and the Israeli-Palestinian Conflict in the New Century: Between Ambition, Idealism, and Pragmatism. Israel Journal of Foreign Affairs, Tel Aviv, v. VII, n.2 , p. 43 - 57, 2013.

ISRAELI PLANS to Build an Additional 12,000 Colonial Housing Units in Jerusalem. Poica - Monitoring Israeli colonization activities in the Palestinian territories, [online], Oct. 1, 2010.Availabe at:<http:// poica.org/2010/10/israeli-plans-to-build-an-additional-12000-colonialhousing-units-in-jerusalem/>. Accessed on: May 20, 2018. 
ISRAELI VIOLATIONS in the Occupied Palestinian Territory during the year 2010. Poica - Monitoring Israeli colonization activities in the Palestinian territories, [online], Feb. 10, 2011. Available at:<http://poica. org/2011/02/israeli-violations-in-the-occupied-palestinian-territoryduring-the-year-2010/>. Accessedon: May 20, 2018.

MRE - Ministério das Relações Exteriores. Resenha de política exterior do Brasil, n. 92. Brasília: Centro de Documentação; Departamento de Comunicações e Documentação, 2003.

Resenha de política exterior do Brasil, n. 104. Brasília: Centro de Documentação; Departamento de Comunicações e Documentação, 2009a.

Resenha de política exterior do Brasil, n. 105. Brasília: Centro de Documentação; Departamento de Comunicações e Documentação, 2009b.

Brazilian Foreign Policy Handbook: Positions adopted by Brazil in 2008 - 2009. Translated by Graham Howells. Brasília: Alexandre de Gusmão Foundation, 2010.

MOVIMENTOS sociais brasileiros em solidariedade ao povo palestino.Carta maior, [online], Jan. 30, 2012. Available at: <http://www.cartamaior.com. $\mathrm{br} /$ ?/Editoria/Movimentos-Sociais/Movimentos-Sociais-brasileiros-emsolidariedade-ao-povo-palestino/2/18705>. Accessed on: May 20, 2018.

MAZIN, M. A. Speeches of President Mahmoud Abbas Abu Mazin in 2009. Palestinian News \&Info Agency WAFA, [online], Feb. 04, 2009. Available at:<http://info.wafa.ps/atemplate.aspx?id=5898\#>. Accessed on: May 20, 2018.

Speeches of President Mahmoud Abbas Abu Mazin in 2007. Delivered on his behalf by Ms. Mayada Bamya - Ambassador of Palestine to Brazil, at the annual conference of the Palestinian community in Brazil. Palestinian News \& Info Agency WAFA, [online], Jan. 26, 2007. Available at:<http:// info.wafa.ps/atemplate.aspx?id=5865>. Accessedon: May 20, 2018.

PAIM, D. de A. O papel do Brasil na paz e na segurança internacionais, sob o enfoque da Defesa Nacional: um estudo da posição brasileira diante do conflito entre Israel e Palestina (1948-2014).70f. Trabalho de Conclusão de Curso - Escola de Comando e Estudo Maior do Exercito, Rio de Janeiro, 2014

SALEH, M. M.; SAAD, W. A. (eds.). Document n. 297. In: The Palestinian documents for the year 2010. Beirut: Al-Zaytouna Centre for Studies \& Consultations, 2015. p. $685-686$. 